\title{
TRANSFORMING IDENTITIES AND RELATIONS: A CASE OF TALIBAN PEACE TALKS IN THE PAKISTANI PRESS
}

\section{Haseeb ur Rehman Warrich ${ }^{1}$, Zaeem Yasin ${ }^{2}$, Zil e Huma ${ }^{3}$, Raza Waqas Ahmad ${ }^{4}, \operatorname{Raazia~Israr}^{5^{*}}$}

${ }^{1}$ Associate Professor, Department of Arts and Media, Foundation University Islamabad, Pakistan; ${ }^{2}$ Assistant Professor, Department of Mass Communication, Lahore College for Women University, Lahore, Pakistan; ${ }^{3}$ Lecturer, Media Studies, University of Balochistan, Quetta, Pakistan; ${ }^{4}$ Ph.D., Scholar, Department of Media and Communication, International Islamic University, Islamabad, Pakistan; ${ }^{5^{*}}$ MS Scholar, Department of Psychology, International Islamic University, Islamabad, Pakistan.

Email: ${ }^{1}$ haseebwaraich79@gmail.com, ${ }^{2}$ zaeem.yasin@1cwu.edu.pk, ${ }^{3}$ zilehuma300@ hotmail.com, ${ }^{4}$ ch.razawaqas@gmail.com, ${ }^{5 *}$ raazia.haseeb@gmail.com Article History: Received on $7^{\text {th }}$ June 2021, Revised on $19^{\text {th }}$ June 2021, Published on $27^{\text {th }}$ June 2021

\section{Abstract}

Purpose of the study: The study examines the role of Pakistani mainstream print media in framing peace talks between the Taliban and the Government of Pakistan from $1^{\text {st }}$ January 2014 till $1^{\text {st }}$ July 2014 . This study focuses on the role played by the print media of Pakistan during the efforts for the peace talks as a LIC.

Methodology: It is a quantitative research study in which researchers have used the content analysis technique to determine how print media framed the peace negotiations between the government and the TTP, editorials, and columns of two English newspapers, namely, Dawn and The News, along with two Urdu newspapers, Jang, Nawe Waqt were analyzed.

Main Findings: The findings of the study show that in the peace talks between the government and TTP, the print media of Pakistan did not engage in constructive talk to facilitate the peace talking process. The media failed to give the communicative space to facilitate the political negotiating process to proceed. Narratives of despair and fear were dominant.

Applications of this study: This study can be used to know about the psychology of newspapers that how they are framing the news, columns, and articles related to complex issues like Taliban peace talks. Along with it, it is necessary to see the role of newspapers in transforming identities and relations.

Novelty/Originality of this study: This study contributed to the existing literature by examining that how print media of Pakistan frame the peace initiatives in the context of resolving the conflict between the Taliban and the government of Pakistan. Apart from it, it is necessary to know about the relationship between the way media was framing the peace negotiations and the way peace talks were taking a turn and whether Pakistani print media played the role of a facilitator of the peace process or framed the peace process as an inevitable risk of more violence or not.

Keywords: Peace Journalism, Terrorism, Low-intensity, The Conflict, Taliban Peace Talks, Pakistani Press, Transforming Identities.

\section{INTRODUCTION}

The Afghan peace process comprises the proposals and negotiations in a bid to end the ongoing war in Afghanistan. Although sporadic efforts have taken place since the beginning of war in 2001, negotiations and the peace movement intensified in 2018 amid talks between the Taliban, which is the main insurgent group fighting against the Afghan government and American troops; and the United States, of which thousands of soldiers maintain a presence within the country to support the Afghan government. Besides the United States, regional powers such as Pakistan, India, China, Russia, as well as NATO play a part that they see as facilitating the peace process, while the Afghan peace group People's Peace Movement sees regional and global powers as a cause of continued war (Yaad, Ziar, 2019).

Though there is an enormous amount of research examining coverage of the conflict in the media, there is very little interest in the role of media when parties in disputes are making an effort to resolve the dispute (Wolfsfeld, 2011; Miller, 2006). Wolfsfeld gives two reasons for this lack of interest in media academics; firstly, he proposes that academics are drawn to the drama of terrorism and war; the peace process doesn't seem to be that interesting. Secondly, the role of the media in the process of peace is far more subtle, complex, and covert, so it becomes less obvious for a study to be examined (Wolfsfeld, 2011).

It is argued that news media has the potential to play a significant role in promoting peace. The Media is expected to play a more responsible position. By emphasizing; the benefits of peace, they can bring legitimacy for the leaders who are working for peace and transform the enemy's images. In the wake of alternative media, it is argued that mainstream media has the responsibility to play an influential role in resolving conflicts and making a difference. All it requires is a commitment to take up the struggle for Peace (Hastings, 2005). At this point, engagement of society (in the peace process) at all levels is encouraged to attain a deep and sustainable peace (McGregor, 2006). A relationship between political control and information control and management of the peace process is found (Wolfsfeld, 1997). The role of 
the media in persuading the public for peace through propaganda and aligning themselves with the authorities is justified as the intentions are benign to mobilize; the public to act and behave in the interests of the power (Wolfsfeld, 2011). And so, even if in promotion of peace if media dependency on the government officials is increased, it is acceptable. The Government can initiate and control events, regulate the flow of information and mobilize; elite support to promote the peace process is warranted.

However, when we talk about the peace process, we also need to understand that all conflicts are not exact. On a broader level, one can divide conflicts into high-intensity conflict (HIC) and Lower Intensity Conflict (LIC). High-intensity conflicts are inter-state conflicts, i.e., state versus state. Whereas low-intensity conflicts are stated versus non-state actors, where violence is much more limited and is pursued by irregular forces against regular armies. LIC includes state versus non-state actors; one side is a state employing armed forces and obeying the laws and rules of war, while the other side is an organization; or a group using irregular forces and systematically violating the laws and regulations of war. It is an asymmetrical relation where the goals of parties engaged in LIC are more political than military. The distinction between home and front, and soldiers and citizens, is blurred (Arsali, 2011). Often, it is in clear violation of international law and norms, a violent organization; deliberately attacks members of the other side and uses its members as human shields. In a conflict of this nature, can the role of the media be considered to be the same? At the same time, if a peace process is initiated in such a conflict, then what should be the role of the media? These are complex questions as in interstate conflicts sometimes, the oppressor is the government in the garb of state interests, and sometimes the nonstate actors are the natural enemies of the state.

Tehreek-e-Taliban Pakistan (TTP), a loose affiliation of militant groups headed by leaders from Pakistan's tribal areas, came to prominence in 2007 with the violent attacks on Pakistanis. Though the number of attempts made to negotiate with them or deal with them forcefully, in 2014, Prime Minister Nawaz Sharif, who throughout his election campaign, had advocated peace talks with the Tehreek e Taliban Pakistan (TTP), was under tremendous pressure to make it through. In the period between January 2014 till July 2014, though, the efforts for peace talks with the TTP were erratic due to the attacks and the killings; it is of significance to understand the role of media in the struggles for peace talks with the TTP. In the case of Pakistan, Tehreek e Taliban Pakistan (TTP) activities have been considered as anti-state in the name of bringing Islamic Shariah laws. Therefore, it falls under the Low-intensity conflict (LIC). Since 2007, the media has been reporting all the attacks and losses, but it is required to look at how media gave coverage to the peace process after the initiatives of the peace process, started in 2014, between the government of Pakistan and TTP.

This study focuses on the role played by the print media of Pakistan during the efforts for the peace talks as a Lowintensity conflict. It aims to examine whether print media framed the peace process between the government and Tehreek-i-Taliban Pakistan (TTP), promoting the efforts of the government of Pakistan? Did it try to achieve some level of reconciliation with the Taliban after more than 11 years of war? Did the editorials and columns of the selected dailies try to persuade the public for peace by aligning themselves with the authorities or accentuated the dangers and risks associated with the compromise with the TTP and a stage has been set for future armed violence?

\section{Media in the wake of domestic terrorism}

Though scholarly interest in research on terrorism and media has grown manifold since September 11, media coverage on domestic terrorism has been relatively minor. Domestic incidents receive little or no coverage, and the few cases which are covered are full of sensationalism. The issues covered are incidents with causalities linked to domestic terrorist groups, targeting airlines, etc. In covering these conflicts, media are not considered neutral and objective; they are supposed to contribute to sensationalizing, mystifying, and beclouding the issues (Mitra, 2016; Yousaf, 1999). The Media is held responsible for the widespread public misconceptions, particularly in the coverage of terrorism attacks (Boaz, 2005; Rahman \& Eijaz, 2014). And if there is national interest involved, media becomes more nationalistic and patriotic and leaves behind norms of quality journalism (Hussain, 2016; Soomro \& Rahman, 2018; Lee \& Maslog, 2005). Researches have shown that media, due to its inherent nature of playing up with conflicts, tends to glamourize; disputes. It has the potential to frame conflict events in such a way that issues gain immediate prominence, which requires immediate action. Often they construct the issues as sites of conflict and contestation by taking the perspectives of political elites, stereotyped imagery, and by dichotomizing; the identities of parties in conflict in distinctly hierarchical terms (Anderson, 2015; Armoudian \& Milne, 2019; Carter, Thomas, \& Ross, 2011; Tenenboim-Weinblatt et al., 2016). It usually serves as a destructive agent by accentuating the dangers and risks associated with the compromise with the 'enemy' by reinforcing the negative stereotypes of the enemy. News stories give prominence to the political elite's perspectives, polarized; notions of national identity are supported, and for future armed violence, the media set the stage. News reports use stereotyped imagery and biased language to dichotomize the parties' identities in the conflict (Carter et al., 2011; Rahman \& Eijaz, 2014). In the peace negotiations between parties, the elite nature of peace talks often excludes or ignores the broader and cross-cutting interests in society (McGregor, 2006). In the case of LIC conflicts, when government or military cannot prevent terrorism and political dissent, media does not play an independent role, which can be harmful in the peace process (Umber et al., 2016; Wolfsfeld, 1997). If one deconstructs news media texts, deep structures have not changed as in the past; even now, media continue to be a significant agent in reflecting the military ethos. The army is projected as heroes and the image of the enemy as 'others.' Eventually, a model of warring society is nourished, ignoring the civilian ethos (Peri, 2007). 


\section{Media as a normative framework for peace}

It is essential to understand that society is better served from a normative perspective when news reports about the conflict are in constructive frames than destructive (Herfroy-Mischler and Friedman, 2018; Reuben, 2009a). As media has a significant role in society, it has the potential to mitigate the conflicts and work for a peaceful resolution (Gilboa, 2009). The role of the media as a guide also comes into play when it starts suggesting possible actions in times of peace process.

In conflicts, what is proposed is that media has rights and responsibilities vis-à-vis terrorism, as terrorism is a matter of public interest and concern; there is no doubt that in certain situations in low-intensity conflict, reportage can affect the operations (Noorani, 1992). Media needs to take their role more seriously by promoting positive, universal core values such as truth, objectivity, and tolerance while covering conflict issues; media has a responsibility in the coverage of terrorism ((Miller, 2006; Yusuf, 1999). In war and reporting, peace journalism can be taught to bring in deescalating the conflict (Abunales, 2016; Ottosen, 2010). It is maintained that in case of terrorists' manipulation and exploitation of the media, the best options for the press in a democratic society are appropriate and effective voluntary, self-restraint and self-regulation measures (Rohner \& Frey, 2007; Walkinson, 1997).

However, the role of the media in finding solutions to the conflict may be considered laudable for its humanitarian spirit is also criticized; in the journalistic objectivity, values being compromised. Also, the news media's role is seen as more of a policymaker rather than of reporter (Reuben, 2009b). At the same time, there is a need to look more carefully at the distinction between peace reporting and objective and factual reporting (Fahmy \& Eakin, 2014). What is equally important is that underreporting does not include bias, and there is no understatement of the actual number of terrorist incidents (Drakos \& Gofas, 2006).

Likewise, it is also argued that while seeing media as a means to resolve the conflict, what one fails to see is that in case of dispute, it is the parties themselves who have to fix it; it is not the role of the media to do so. Although society at large may be interested in resolving the conflict, the role of the media can be seen in the facilitative role rather than an evaluative role in the coverage of conflict, one that ultimately lays the ground for the parties to engage in constructive problem solving (Reuben, 2009b). The framing of the peace process in the media needs to be linked with the political realities existing and how they fit into the meta-narrative that gave birth to the peace process (Yadgar, 2003). The more significant function of media outlets is to help develop a communicative space to enable the political negotiation process to proceed, rather than it being of that process itself (Spencer, 2004). To realize; a deep, sustainable peace, the peace process, at all levels of society, macro-level and at the civil society level, must be engaged equally (McGregor, 2006:

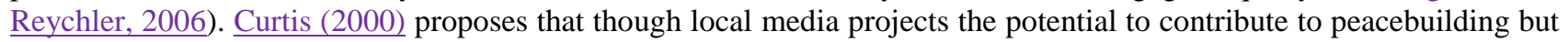
the media don't need to show absolute success. Media does play an essential role in constructing the problem historically but is not directly part of the political talk's process. Media, mainly television news, helps to develop a communication space to enable the political negotiation process to proceed but is not the process of peace itself (Spencer, 1997).

Researches have shown that in the case of HIC and LIC, the role of the media has been more in line with government policies and public sentiments. It is argued that media might be playing a significant role in conflict escalation or conflict resolution. Still, many other actors play an important role in the way conflict is framed and the way conflict-related knowledge is produced. These include policy-makers, academic circles, think tanks, social media, independent experts, governments, and international organizations. The media is just one of the actors. The media's role in conflict and peacebuilding aligns with how the other institutions are taking the conflict or peace process. Suppose other institutions, including the government and people, are seriously interested in the peacemaking process. In that case, the media also complements the efforts, but if there is no will to make a peace process successful, then the media also frames the issue in war frames. So, we need to understand that in an actual peace support operation, the media is present not as a maker of the peace process but as one of the facilitators of the peace process (Smith, 2004).

The present study aims to study whether Pakistani print media played the role of a facilitator of the peace process or framed the peace process as an inevitable risk of more violence?

\section{Objectives of this study}

1. To examine whether print media of Pakistan frame the peace initiatives in the context of resolving the conflict between the Taliban and the government of Pakistan.

2. To know about the relationship between the way media was framing the peace negotiations and the way peace talks were taking a turn.

3. To study whether Pakistani print media played the role of a facilitator of the peace process or framed the peace process as an inevitable risk of more violence.

\section{Research Questions}

RQ1. Did the print media of Pakistan frame the peace initiatives in the context of resolving the conflict between the Taliban and the government of Pakistan? 
RQ2. Is there any relationship between the way media was framing the peace negotiations and the way peace talks were taking a turn?

\section{METHODOLOGY}

It is a quantitative research study in which researchers have used the content analysis technique to determine how print media framed the peace negotiations between the government and the TTP, editorials, and columns of two English newspapers, namely Dawn and The News, and two Urdu newspapers, Jang and Nawa i Waqt, were analyzed. The time period selected was from January 1, 2014, till July 1, 2014. In the light of the peace and war journalism frames, as suggested by Gultang Gultang (1999), four categories of peace and war journalism frames were made (Lacasse \& Forster, 2012; Lee \& Maslog, 2005). In the light of the four categories of peace and war journalism further, three categories were made. If an article had more peace frames and supported the peace initiatives by the government, it was categorized; as 'supportive'; if there were more war frames and the article was against the peace process, it was categorized; as 'unsupportive'; and if it supported the peace talks but was critical of the way the government or TTP was behaving it was categorized; as 'mixed.' Three coders were trained till they reached Cohen's $\kappa=.80$ on each framing category. Based on these categories, a coding manual is formulated.

\section{FINDINGS AND DISCUSSION}

In the period of six months, a total number of $264(42.3 \%)$ editorials and $360(57.7 \%)$ columns related to government and Taliban conflict and peace process were published in selected newspapers. In English dailies, out of the 268 news articles published with reference to peace talks, 98(36.6\%) editorials and 170(63.4\%) columns were published, and in Urdu dailies out of $356,166(46.6 \%)$ editorials and $190(53.4 \%)$ columns were published. Thus, findings show that Urdu dailies (356), in their editorials and columns, gave more coverage to the issue compare to English dailies (268).

Table1: Language and genre-wise coverage to the Taliban and peace process

\begin{tabular}{cccc}
\hline Language & Editorials & Columns & Total \\
\hline English & $98(36.6 \%)$ & $170(63.4 \%)$ & $268(42.9 \%)$ \\
Urdu & $166(46.6 \%)$ & $190(53.4 \%)$ & $356(57.1 \%)$ \\
\hline Total & $264(42.3 \%)$ & $360(57.7 \%)$ & 624 \\
\hline
\end{tabular}

Source: Newspapers

Table 2: Type of coverage to the Taliban and peace process

\begin{tabular}{cccc}
\hline Language & Supportive & Unsupportive & Mixed \\
\hline Urdu & $10(17.5 \%)$ & $154(46.0 \%)$ & $104(44.8 \%)$ \\
\hline English & $47(82.5 \%)$ & $181(54.0 \%)$ & $128(55.2 \%)$ \\
\hline Total & $57(9.1 \%)$ & $335(53.6 \%)$ & $232(37 \%)$ \\
\hline
\end{tabular}

Source: Newspapers

Findings in Table 2 show a significant difference between supportive, unsupportive, and mixed frames with reference to Government-TTP peace negotiations. Out of 624 editorials and columns on peace negotiations, 335 (53.6\%) were against peace negotiations, and only $57(9.1 \%)$ were supportive of peace negotiations; $232(37 \%)$ had mixed frames. Thus, the sample has shown a significant difference in the peace negotiation frames $(\chi 2=189.93, \mathrm{df}=2, \mathrm{p}<0.000)$.

In English dailies, news articles (editorials and columns) supportive of peace negotiations were 47 (82.5\%), and in Urdu dailies, only $10(17.5 \%)$ were supportive of peace negotiations. This shows a significant difference in the editorials of the two languages.

However, news articles in English and Urdu dailies against peace negotiations were not significantly different. Against peace negotiations, English dailies had 181(54\%), and Urdu dailies had 154(46\%) news articles published. There was also not much difference between Urdu and English dailies in the mixed frames on peace negotiations.

Table 3: Newspaper-wise comparison of Government-TTP peace negotiation frames

\begin{tabular}{|c|c|c|c|c|}
\hline \multirow[b]{2}{*}{ Newspapers } & \multicolumn{4}{|c|}{ Negotiation Frames } \\
\hline & Peace negotiations & Against Peace Negotiations & Mixed & Total \\
\hline Dawn & $1(1.8 \%)$ & $106(31.6 \%)$ & $12(5.2 \%)$ & $119(19.1 \%)$ \\
\hline The News & $9(15.8 \%)$ & $48(14.3 \%)$ & $92(39.7 \%$ & $149(23.9 \%)$ \\
\hline Jang & $36(63.2 \%)$ & $46(13.7 \%)$ & $48(20.7 \%$ & $130(20.8 \%)$ \\
\hline Nawa-i-Waqt & $11(19.3 \%)$ & $135(13.7 \%)$ & $80(34.5 \%$ & $226(36.2 \%)$ \\
\hline
\end{tabular}

Source: Newspapers 
Table 3 findings show that the maximum coverage of the issue was in the daily Nawa-i-Waqa 226 news articles (36.2\%). In the daily The News, news articles supporting peace negotiations were only $9(15.8 \%)$ whereas, Daily Jang had most news articles supportive of the peace negotiations $36(63.2 \%)$. This is an exciting finding as both newspapers belong to the Jang Group of Publications. Dawn had only one column in support of peace negotiations, and 106 (31.6\%) editorials and columns were against the peace negotiations, which means that maximum news articles against the peace negotiations were published in the daily DAWN. The other three dailies had more or less the same frequency of editorials and columns against the peace negotiations. Daily News had the most news articles on mixed frames, 92 (39.7\%) where peace talks were supported but, either the government steps were criticized, or the violent reactions of the TTP were condemned.

Table 4: Genre-wise comparison of TTP peace negotiation frames

\begin{tabular}{cccc}
\hline Genre & Supportive & Unsupportive & Mixed \\
\hline Columns & $27(47.4 \%)$ & $144(43.0 \%)$ & $93(40.1 \%)$ \\
\hline Editorials & $30(52.6 \%)$ & $191(57.0 \%)$ & $139(59.9 \%)$ \\
\hline
\end{tabular}

Source: Newspapers

In Table 4, findings show that 191(57\%) editorials were against peace negotiations and 144(43\%) columns were against peace negotiations. Thus, the findings show that there was not much difference in the coverage of the peace negotiations in the editorials and columns.

Table 5: Month-wise comparison of TTP peace negotiations frames in the year 2014

\begin{tabular}{ccccccll}
\hline Month & Supportive & Unsupportive & $\begin{array}{c}\text { Mixed } \\
\text { frames }\end{array}$ & Total & $\begin{array}{c}\text { Terrorist } \\
\text { attacks }\end{array}$ & Peace Talk status \\
\hline Jan & $14(24.6 \%)$ & $71(21.2 \%)$ & $40(17.2 \%)$ & $\begin{array}{c}125 \\
(20.0 \%)\end{array}$ & 5 & Announcement of peace talks \\
\hline Feb & $33(57.9 \%)$ & $113(33.7 \%)$ & $92(39.7 \%)$ & $\begin{array}{c}238 \\
(38.1 \%)\end{array}$ & 2 & $\begin{array}{l}\text { Negotiations first round of peace } \\
\text { talks } \\
\text { Talks suspended due to TTP attack }\end{array}$ \\
\hline Mar & $7(12.3 \%)$ & $54(16.1 \%)$ & $55(23.7 \%)$ & $\begin{array}{c}116 \\
(18.6 \%)\end{array}$ & 1 & $\begin{array}{l}\text { TTP announces a month-long } \\
\text { ceasefire } \\
\text { Talks resume }\end{array}$ & \\
\hline Apr & $0(0.0 \%)$ & $34(10.1 \%)$ & $21(9.1 \%)$ & $\begin{array}{c}55 \\
(8.8 \%)\end{array}$ & 3 & TTP ends ceasefire & \\
\hline May & $1(1.8 \%)$ & $18(5.4 \%)$ & $11(4.7 \%)$ & $\begin{array}{c}30 \\
(4.8 \%)\end{array}$ & 0 & \\
\hline June & $2(3.5 \%)$ & $45(13.4 \%)$ & $13(5.6 \%)$ & $\begin{array}{c}60 \\
(9.6 \%)\end{array}$ & 3 & $\begin{array}{l}\text { Attack on Karachi Airport } \\
\text { Announcement of Zarbe Azab }\end{array}$ \\
\hline
\end{tabular}

\section{Source: Newspapers}

Regarding research question 2, the finding shows that there is a relationship between the way media was framing the peace negotiations and the way peace talks were taking a turn. Results in Table 6 show a significant difference in the coverage of peace negotiations in the six months. The sample has shown a significant difference between the framing of negotiation in six months $\left(\chi^{2}=33.196, \mathrm{df}=9, \mathrm{p}<0.001\right)$. There has been a gradual decline in the coverage from January till the end of June 2014. In the month of February, when finally, the committee sat for the peace talks, the content is maximum.

Interestingly, articles against peace talks are less in January; however, they increased in February and March. In June, when army action was taken, the coverage on the peace talks had reduced, editorials and columns against the peace talks were significantly high. Though in February, 238 (38.1\%) editorials and columns were maximum on Government- TTP peace negotiations, most of the editorials and columns $113(47.4 \%)$ were against the peace talks, only $33(13.8 \%)$ were supportive of the peace process. Compared to other months, only in February, we see maximum coverage to support the Government-TTP peace negotiation because that was the time when the first round of peace negotiations commenced. Findings show that in the first three months of the year when the government was serious in peace talks with TTP, the coverage in the editorials and columns is high from the coverage in April, May, and June.

With reference to RQ1, results show that even if there was an apparent will of the government to resolve the issue through talks, the Pakistani press did not support peace negotiations. Newspapers were sceptical about the success of the negotiations, not only because TTP was considered a violent party and any negotiations with them will be illegitimate but also because of the vague policies of the government. The government was criticized for not being clear about its policy, not taking the parliament into confidence. Moreover, the team negotiating with the Taliban was not competent enough to take the talks through. Therefore, the dailies insisted that the option for the government was to combat TTP with force, as risks with the compromise with the TTP proposed future arms violence. 


\section{TTP saw only as a terrorist Party}

The dailies considered TTP to be "the militancy threat (which) is immediate and dire and needs to be combated aggressively." ("The militancy threat," 2014). Peace talks were considered to be useless because "the Taliban are trained only to pull a trigger" (Irfan, 2014). Moreover, engagement with the TTP on peace talks was considered unconstitutional because it did not recognize the Constitution of Pakistan.

The TTP is an illegal terrorist organization, and it violates the constitution for the state to engage with it. The outfit has declared war on Pakistan and has claimed responsibility for attacking security installations and killing our soldiers. The government would be legitimizing all those terrorist actions by unconditionally negotiating with them. However, there is no indication that the group is willing to give up violence and accept the nation's constitution (Hussain, 2014).

TTP was criticized for its narrow interpretation of Sharia and stance against the modern Islamic Republic of Pakistan.

WHY is it that, those who promote enforcement of a regressive brand of Sharia, those who endorse a worldview that supports turning back the hands of the clock on human progress, those who were back replacing the nation-state system with a caliphate ruling by the sword, those who support the Al Qaeda form of jihad, are also the ones who sympathize with the Tehreek-i-Taliban Pakistan (TTP) and insist that no force be used against these 'misguided' terrorists irrespective of their crimes? (Sattar, 2014, p. 6)

The talks with TTP are considered to be in vain as "there's no common ground on the critical contentions of both sides. You can get to ceasefires, prisoner exchanges, strategic pauses, and buy-out deals, but the TTP has an ideological bend that cannot accept the modern constitutional remit (Yousaf, 2014). Therefore, the way forward to bring an end to extremism in the country is considered a simple step: we must dissociate from it (Hussain, 2014).

Talks with the Taliban were considered to be:

If wishes were horses, peace talks with terrorists would produce happy endings. It has been said before, and it needs to be said again: the predominant opposition to talks is not rooted in the belief that exterminating members of the TTP-led terror syndicate or revenge is a goal as desirable as peace (Sattar, 2014, p. 6).

TTP was considered a terrorist organization is known for killing innocent people, so any negotiations with them were considered completely unacceptable.

There is absolutely no doubt now that terrorism cannot be combated with dialogues. Nation tried to support the government's stance for peace negotiations, which was perceived by the extremists as a weakness. The government had repeatedly said that if negotiations failed, army operations would take place. Negotiations have failed, the nation is united, the army is ready to eradicate the evil of terrorism, now the only way to rid the country from terrorism is an Army operation. If the government is afraid of terrorists, please pack up and go home, don't be responsible for more deaths ("TTP as a terrorist organization," 2014, p. 6).

\section{Government Criticized}

The government was warned about the consequences of the peace talks as ' $\ldots$ the Taliban are not interested in any kind of talks (Nawa i Waqt (2/1/13) and it will only be a matter of time that the reality of the situation will become clear. TTP attacks were considered the only means that the militants knew to achieve their objectives which, all sides must know, and yet the pretense continues of peace through negotiations ("All sides must know," 2014). The apprehensions about the peace talks were considered to be a failure because "talking to the TTP is a policy rooted in fear..." ("Talking to the TTP," 2014). The talks... are designed to fail. This is because there is no middle ground that can be reached (Rana, 2014, p. 6).

The initiation of peace talks with TTP was severely criticized as the first wrong step to legitimize TTPs' violence in the country.

HALF the battle was lost long ago when our national leaders embraced the militant narrative and legitimized violence. Now it is complete capitulation. So, it doesn't matter how many more people are killed, religious places bombed, or soldiers blew up; it is not our war anyway. (Hussain, 2014, p. 7)

The Government was advised first to take all the possible steps to stop the drone attacks. And secondly, it needs to make sure that no one should challenge the government's writ, and all those who try to do so should be dealt with severely. As discussed in "The Government dual policy" (2014) 
The government needs to stop its dual policy to bring peace to the country. On the one hand, it has banned the organizations which are responsible for terrorism in the country, and on the other hand, they are ready to negotiate with the terrorist organization. This way, they are only encouraging the terrorist to carry on with their terrorist activities. ("The Government dual policy," 2014, p. 7)

The government was criticized that in the name of negotiations, they have put the entire nation into danger (“Government dual policy," 2014).

If anything has become clear amidst all the fog of peace, the press for talks is very much an initiative of the prime minister and his interior minister. Repeatedly, both men have owned their policy and sought to push ahead with it in the face of near-universal disapproval. But neither seems willing to explain to parliament, the media, or the public precisely what they are doing and how far they are ready to go. The approach seems to be: trust us, we won't let you down. But trust in such matters is always a scarce commodity, doubly so when the interior minister suggests the TTP is a friendly entity. The prime minister needs to explain clearly what he is authorizing; and why when it comes to talks with the TTP ("Talks with the TTP," 2014, p. 6).

The government was advised to take serious steps to combat the terrorist activities of TTP.

The whole county is under threat from the terrorists...now; there is no room for consideration or cowardice; courageous steps are required... ("Threats from the terrorists," 2014, p. 7).

... the government, in a joint effort with the military leadership, should continue to work on a plan to knock off the remaining TTP strongholds while also tightening security in the cities and towns where blowback can be expected. That would send the clearest possible signal to the TTP that negotiations are not the only option - that the state security apparatus is able and ready to protect the citizenry and the state itself. If that resolve is shown and maintained, the TTP's room to manoeuvre will diminish greatly ("Government military leadership," 2014, p. 6).

It may sound like a cliché, but talks need to be conducted from a position of strength. This point is even more relevant where a state is negotiating with terrorists. Of course, ideological support for the terrorists in influential segments of society does complicate matters. But any sign of weakness is pounced upon by the terrorists, as already we have evidenced in the killing of our soldiers (Raza, 2014, p. 6).

\section{Military operation the only option}

The failure of the peace talks was warned right from the beginning, and the military operations were considered inevitable.

I have reasonable certainty that there will soon be a series of military operations against TTP groups. How will these be qualitatively different from previous operations? (Hussain, 2014, p. 6).

The obstinate attitude of TTP was thought could only be handled with brutal force alone rather than talks. TTP was considered to be "fixed with kicks, not with talks" (Raja, 2014, p. 7).

...the choice is clear either we fight the Taliban's or hand over the country to them (Zaidi, 2014, p. 9).

The support and confidence in the Army to combat TTP was far more than the confidence in the politicians to continue with the peace talks, and "military operation was considered to be inevitable" ("Peace talks and military operations," 2014, p. 7).

It seems that talks are leading to failures, and Army will have to take action.

And when it happens, it will be the victory of the truth as the Army and people

of Pakistan are on the same page ("Talks are leading to failures," 2014, p. 7).

The Army was considered to be on the number one hit list of TTP, "The army is Enemy No 1, and the TTP is always aching to hit it (Almeida, 2014, p. 6). 
The extremism and the violence in the TTP were considered to be an inevitable threat to the peace of the country, and the only option put forward was to fight them with military force:

That is why it is crucial to fight the militants, destroy their hideouts and safe havens, uproot the infrastructure that brainwashes, train, and dispatches suicide bombers, and prosecute those guilty of waging war on the people and state of Pakistan. But, does the government have any such intention? Or will it continue to be on the defensive, capitulating to the terrorists and ceding more and more ground? The state needs to assert itself and display some leadership if the militant onslaught is to be stopped ("The extremism and the violence in the TTP," 2014, p. 6).

\section{Counter Discourse}

Though the coverage of the peace talks was relatively consistent, in all six months, there were few frames supportive of peace negotiations. The peace talks were supported on the grounds that 'no form of violence will be tolerated. Both must try their best to make the talks a success by upholding the truce cease-fire agreement ("No form of violence will be tolerated," 2014, p. 9). All possible efforts must be made to make the talks successful. Though in the past, the talks have failed and both parties have resorted to violence, but this time a conscious effort was needed to make sure that the talks are successful ("Past talks have failed," 2014, p. 9). Third mischievous power must be controlled to make the talks successful. For the peace in the country, TTP was also considered one of the stakeholders, and without taking them seriously, the country could not talk about the future of Pakistan.

Therefore, let's talk about the possible success of these talks... let's talk about the future of Pakistan once these talks succeed. Let's support these talks, which recognize the local Taliban and other Al-Qaeda allies as legitimate players and stakeholders in our state. The prime minister and his men are on the right course... Pakistan is heading in the right direction. Let's talk and keep talking ... that the best we can do ("For the peace in the country," 2014, p. 8).

The dailies also touched on the effect war would have on ordinary citizens.

What strategy should a journalists adopt to stay away, at least ideologically, from the conflict in which the stakeholders — both the military and militants are more interested in the aesthetics of war than concerned by the loss of innocent lives? (Arshad, 2014, p. 6).

\section{CONCLUSION}

The findings of the study show that in the peace talks between the government and TTP, the print media of Pakistan did not engage in constructive dialogue to facilitate the peace talking process. The media failed to give the communicative space to promote the political negotiating process to proceed. Narratives of despair and fear were dominant. TTP was considered to be an extremist, violent group with no hope of ever coming to any sort of reconciliation. The government was not only criticized for taking the initiative but was also considered to be responsible for giving time to TTP so that they can bring more violence to the country. The findings did not support the argument that if the government is serious about negotiation, the media also follows (Wolfsfeld, 2011). Pakistani print media stance was quite independent of the stance of the government stance. Newspapers repeatedly warned the policymakers and readers of the dangers of any peace talks with the TTP. The condemnation of the extremist view of TTP was quite apparent. It is argued that the local newspapers would use more peaceful journalism frames and present a less pessimistic and negative view of the conflict (Drakos \& Gofas, 2006). Pakistani newspapers presented the conflict more as a simple open and shut case. Where TTP just needed to be controlled through force and not through any negotiations. Pakistani press was very clear about TTP not just as the enemy of the state but also of the people of Pakistan.

From a normative perspective, it is argued that society is better served if the conflict coverage is constructive rather than destructive (Reuben, 2009a). As the way media reports the conflicts has an impact on the conflict and conflict resolution and those involved in the conflict and disputes.

\section{LIMITATION AND STUDY FORWARD}

In the Low-Intensity Conflicts peace process, like government-TTP peace talks, it does become quite problematic to speak for peace journalism, especially when one of the conflicting parties is resorting to extreme violence and challenging the constitution. Maybe terrorism needs to be understood as a social problem in the policymaking process. What needs to be understood is that peacebuilding is a slow process that requires a lot of patience, as it is full of uncertainties and competing values and interests (Reychler, 2006). Those who want to make a difference must not lose sight of the big picture and ground political and social realities. They need to explore ways to facilitate understanding the viewpoints of all the decision-makers in the conflict. Those who want to make a difference must not lose sight of the big picture and ground political and social realities. They need to explore ways to facilitate understanding the viewpoints of all the decision-makers in the conflict. For further researches, this study can be used to know about the psychology of newspapers that how they are framing the news, columns, and articles related to complex issues like Taliban peace talks. 


\section{ACKNOWLEDGEMENT}

It was not a funded study and was not part of any project. The data was provided by the American center in the US embassy, Islamabad, Pakistan, by using its Lexis-Nexis subscription.

\section{AUTHORS CONTRIBUTION}

In this study, Dr. Haseeb ur Rehman Warrich is the primary author, who has supervised the team from generating the idea to conclusion. His scholarly contribution has made this research possible. Dr. Zaeem Yasin has worked on methodology and, coding sheet, and findings. Zil e Huma has collected and interpreted the data. Codes were made by Raza Waqas Ahmad, and he assisted Zil e Huma with data collection and interpreting. Introduction and literature review was incorporated by Raazia Israr, who worked under the guidance of Haseeb ur Rehman Warrich.

\section{REFERENCES}

1. Abunales, D. (2016). Peace Journalism: Preparing Aspiring Journalists to Value Culture of Peace. Asia Pacific Media Educator, 26(2). https://doi.org/10.1177/1326365X16666851

2. Almeida, C. (2014, February 16). The army is Enemy No 1 the TTP is always aching to hit it. Dawn, p. 6.

3. All sides must know (2014, February 2). Dawn, p. 7.

4. Anderson, L. (2015). Countering Islamophobia media representations: The potential role of peace journalism. Global Media and Communication, 11(3), 255-270. https://doi.org/10.1177/1742766515606293

5. Armoudian, A., Milne, B. (2019). The politics of blame: Mass media messages and political violence during peace negotiations. Journalism, 1-21. https://doi.org/10.1177/1464884919860280

6. Arshad, I. S. (2014, February 15). What strategy should journalists adopt? Dawn, p. 6.

7. Arsali J. (2011). States vs. Non-State Actors: Asymmetric conflict of the $21^{\text {st }}$ century and challenges to Military Transformations: INEGMA Special Report No.13.

8. Boaz, C. (2005). War and peace in the Media. Peace Review: A Journal of Social Justice, 17(4), 335-339. https://doi.org/10.1080/10402650500374587.

9. Carter, D. L., Thomas, R., \& Ross, S. D. (2011). You are not a friend. Journalism Studies, 12(4), 456-473. https://doi.org/10.1080/1461670X.2010.530972

10. Curtis, D. E. (2000). Conflict Peacebuilding Projects in Rwanda and Bosnia. Canadian Journal of Development Studies, 21(1), 141-166. https://doi.org/10.1080/02255189.2000.9669886

11. Drakos, K., \& Gofas, A. (2006). The Devil You Know but Are Afraid to Face: Underreporting Bias and Its Distorting Effects on the Study of Terrorism. The Journal of Conflict Resolution, 50(5), 714-735. ttps://doi.org/10.1177/0022002706291051

12. Fahmy, S. \& Eakin, B. (2014). High drama on the high seas: Peace versus war journalism framing of an Israeli / Palestinian related incident. The International Communication Gazette, 1(76), 86-105. https://doi.org/10. $1177 / 1748048513504046$

13. For the peace in the country. (2014, February 3). News, p. 8.

14. Galtung, J. (1999). Conflict transformation by peaceful means: The Transcend method. UN.

15. Gilboa, E. (2009). Media and conflict resolution: A framework for Analysis. Marquette Law Review, (93), 87110.

16. Government dual policy. (2014, March 7). Nawae Waqt, p. 7.

17. Government dual policy. (2014, January 1). Nawae Waqt, p. 7.

18. Government military leadership. (2014, January 14). Dawn, p. 6.

19. Hastings, T. H. (2005). Media messaging and conflict. Peace Review: A Journal of Social Justice, 17(4), 389395. https://doi.org/10.1080/10402650500374652

20. Herfroy-Mischler, A., Friedman, E., (2018). The 'blame game frame': Ethical blame patterns and media framing upon negotiations failure in the Middle East. Journalism, 1-20.

21. Hussain, K. (2014, February 27). The way forward to bring an end to extremism in the country. Dawn, p. 7.

22. Hussain, M. (2014, February 21). Military operation the only option. Dawn, p. 6.

23. Hussain, Z. (2014, February 25). The TTP is a proscribed terrorist organization. Dawn, p. 6.

24. Hussain, Z. (2014, January 1). HALF the battle was lost long ago when our national leaders embraced the militant narrative and legitimized violence. Dawn, p. 7.

25. Hussain, S. (2016). Media coverage of Taliban: Is peace journalism the solution? Asia Pacific Media Educator, 26(1), 31-46. https://doi.org/10.1177/1326365X16640340

26. Irfan, S. (2014, March 10). The Taliban are trained only to pull a trigger. Dawn, p. 6.

27. Lacasse, K., \& Forster, L. (2012). The war next door: Peace journalism in US local and distant newspapers' coverage of Mexico. Media, War \& Conflict, 5(3), 223-237. https://doi.org/10.1177/1750635212447907

28. Lee, S. T. \& Maslog, C. C. (2005). War or peace journalism? Asian newspaper coverage of conflicts. Journal of Communication, 55(2), 311-329. https://doi.org/10.1111/j.1460-2466.2005.tb02674.x

29. Martin, S. E. (2006). Media Pools and Military Interventions in the 1980s and 1990s. Journal of Peace Research, 43(5), 601-616. https://doi.org/10.1177/0022343306067062 
30. McGregor, L. (2006). Beyond the time and space of peace talks: Re-appropriating the peace process in Sri Lanka. International Journal of Peace Studies, 2(1), 39-57.

31. Miller, D. (2006). The media, propaganda and the peace process in Ireland. Media in Ireland: Issues in Broadcasting. Retrieved from http://www.medialens.org/articles/the articles/northern ireland.

32. Mitra, M. (2016). Socio-cultural contexts and peace journalism: A case for meso-level comparative sociological investigation of journalistic cultures. Journalism, 1-17.

33. Noorani, A. (1992). Media and Terrorism. Economic and Political Weekly, 27(26), 1301-1302.

34. No form of violence will be tolerated. (2014, March 4). Jang, p. 9.

35. Ottosen, R. (2010). The war in Afghanistan and peace journalism in practice. Media, War \& Conflict, 3(3), 261278. https://doi.org/10.1177/1750635210378944

36. Peace talks and military operations. (2014, January 21). Nawe Waqt, p. 7.

37. Past talks have failed. (2014, March 3). Jang, p. 9.

38. Peri, Y. (2007). Intractable conflict and the media. Israel Studies, 12(1), 79-102. https://doi.org/10.29 79/ISR.2007.12.1.79

39. Rahman, B. H. \& Eijaz, A. (2014). Pakistani media as an agent of conflict or conflict resolution: A case of Lal Masjid in Urdu and English dailies. Pakistan Vision, 15(2).

40. Raja, A. Z. (2014, March 5). The obstinate attitude of TTP was thought could only be handled with brutal force. Nawae Waqt, p. 7.

41. Rana, A. M. (2014, February 9). The talks... are designed to fail. Dawn, p. 6.

42. Raza, A. M., (2014, February 23). Government in a joint effort with the military leadership. Dawn, p. 7.

43. Reuben, R. C. (2009a). The impact of news coverage on conflict: Toward greater understanding. Marquette Law Review, 45-83.

44. Reuben, R. C. (2009b). The Impact of News Coverage on Conflict: Toward Greater Understanding. Marquette Law Review, 93, 45-83.

45. Reychler, L. (2006). Challenges of peace research. International Journal of Peace Studies, 11(1) 1-16.

46. Rohner, D., \& Frey, B. S. (2007). Blood and Ink! The common-interest-game between terrorists and the media. Public Choice, 133 (1/2), 129-145. https://doi.org/10.1007/s11127-007-9182-9

47. Sattar, B. (2014, February 24). WHY is it that those who support enforcement of a regressive brand of Sharia. Dawn, p. 6.

48. Sattar, B. (2014, February 3). If wishes were horses, peace talks with terrorists would produce happy endings. Dawn, p. 6.

49. Savun, B., \& Phillips, B. J. (2009). Democracy, Foreign policy and terrorism. The Journal of Conflict Resolution, 53(6), 878-904. https://doi.org/10.1177/0022002709342978

50. Scott, J. L. (2001). Media congestion limits media terrorism. Defence and Peace Economics, 12(3), $215-227$. https://doi.org/10.1080/10430710108404985

51. Slone, M. (2000). Responses to media coverage of terrorism. Journal of Conflict Resolution, 44(4), 508-522. https://doi.org/10.1177/0022002700044004005

52. Smith, K. (2004). The importance of the Media in Peace operations. Small wars \& Insurgencies, 15 (2), $158-$ 167. https://doi.org/10.1080/0959231042000282661

53. Soomro, M. A., \& Rahman. B. H. (2018). War on terror partnership and growing/mounting/increasing/rising militant extremism in Pakistan. South Asian Studies, 33(2), 583-588.Spencer, G. (1997). Talking peace: Political communications through the television news media and the Northern Ireland peace process. Contemporary Politics, 267-276. https://doi.org/10.1080/13569779708449930

54. Spencer, G. (1997). Talking peace: Political communications through the television news media and the Northern Ireland peace process. Contemporary Politics,3(3), 267-276. https://doi.org/10.1080/13 $\underline{569779708449930}$

55. Spencer, G. (2004). The impact of television news on the Northern Ireland peace negotiations. Media Culture and Society, 26(5), 603-623. https://doi.org/10.1177/0163443704044218

56. Steven, M. C., \& Gruenewald. J. (2006). The media's coverage of domestic terrorism. Justice Quarterly, 23(4), 428-461. https://doi.org/10.1080/07418820600985305

57. Tenenboim-Weinblatt, K., Hanitzsch, T., \& Nagar, R. (2016). Beyond peace journalism. Journal of Peace Research, 53(2), 151-165. https://doi.org/10.1177/0022343315609091

58. Talking to the TTP is a policy rotted in fear. (2014, January 14). Dawn, p. 7.

59. The extremism and the violence in the TTP. (2014, February 23). Dawn, p. 6.

60. Threats from the terrorists. (2014, February 20). Nawae Waqt, p. 7.

61. Talks with the TTP. (2014, March 3). Dawn, p. 6.

62. Talks are leading to failures. (2014, February 15). Nawae Waqt, p. 7.

63. There is absolutely no doubt now that terrorism cannot be combated with dialogues. (2014, February 18). Nawae Waqt, p. 7.

64. Umber, S., Ghauri M. J., \& Shahzad, M. (2016). Pakistan press stance on Government-TTP Talks: Analysis of the editorial coverage in dailies: The Nation and The News. Journal of Punjab University Historical Society, 29(1), 149-169. 
65. Walkinson, P. (1997). The media and the terrorism: A reassessment. Terrorism and Political Violence, 9(2), 5164. https://doi.org/10.1080/09546559708427402

66. Wolfsfeld, G. (1997). Fair weather friends: The varying role of the news media in the Arab-Israel peace process. Political Communication, 14(1), 29-48. https://doi.org/10.1080/105846097199524

67. Wolfsfeld, G. (2011). The propaganda of peace: The role of media and culture in the Northern Ireland Peace process. Political Communication, 28 (3), 400-402. https://doi.org/10.1080/10584609.2011.588870

68. Yadgar, Y. (2003). 'True Peace' to 'the Vision of the New Middle East': Rival images of peace in Israel. Journal of Peace Research, 40(2), 177-193. https://doi.org/10.1177/0022343303040002003

69. Yusuf, S. (1999). Nigeria's membership in the OIC: Implications of print media coverage for peace. Journal of Muslim Minority Affairs, 19(2), 235-247. https://doi.org/10.1080/13602009908716439

70. The military threat is immediate. (2014, January 25). Dawn, p. 7.

71. Yaad, Ziar (March 24, 2019). Peace Movement Blames Foreign Countries For Afghan War. TOLOnews. Archived from the original on May 30, 2021. Retrieved June 3, 2021.

72. Yousaf, M. (2014, March 11). The talks with TTP were considered to be in vain. Dawn, p. 6.

73. Zaidi, H. H. (2014, January 27). The choice is clear wither we fight the Taliban's or hand over the country. News, p. 9. 